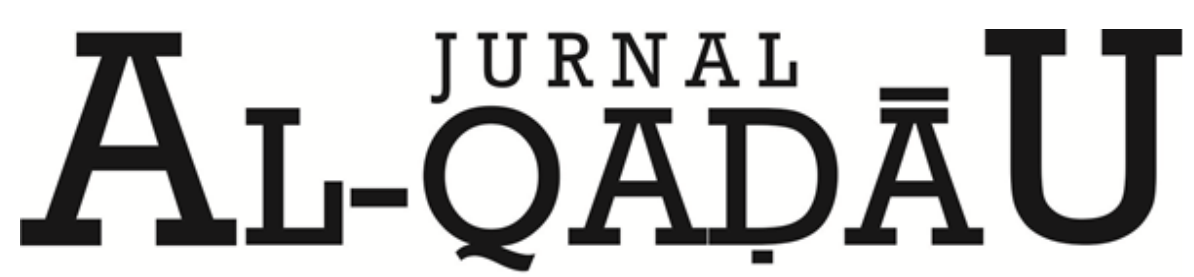

PERADILAN dan HUKUM KELUARGA ISLAM

\title{
Sistem Bagi Hasil pada Pelelangan Ikan di Kecamatan Galesong Utara Kabupaten Takalar
}

Profit Sharing System at Fish Auction in Kecamatan Galesong Utara Takalar District

Muhammad Irfan

Dosen Fakultas Syariah dan Hukum UIN Alauddin Makassar

Email: lewaparis@yahoo.co.id

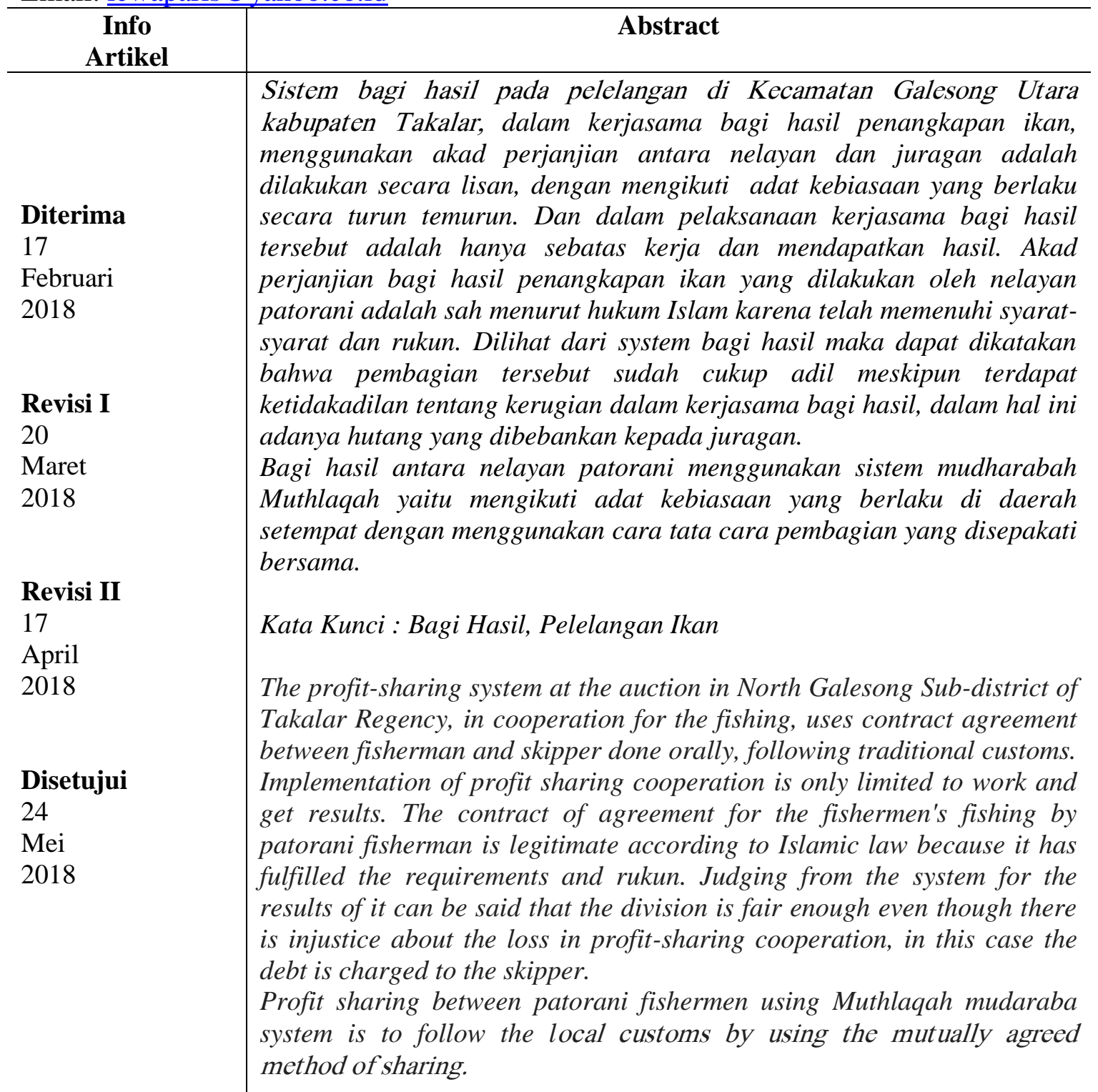

Keyword: profit-sharing, Fish Auction 


\section{A. PENDAHULUAN}

Indonesia sebagai negara kepulauan yang memiliki daerah pesisir sangat luas dan diperkirakan 240 juta jiwa (60\% jumlah penduduk) hidup di wilayah pesisir (sampai dengan $50 \mathrm{~km}$ dari pantai), dengan $22 \%$ penduduknya hidup dan tinggal di daerah pesisir sebagaimasyarakat desa pesisir. Ada sekitar 4.735 des a dari 64.439 desa yang ada di berbagai propinsi di Indonesia dapat dikategorikan sebagai desa pesisir.Dengan sumberdaya alamnya yang melimpah, ikan, terumbu karang dan lain sebagainya, belum dieksplorasi secara optimal.Salah satu propinsi yang memilki banyak wilayah laut adalah propinsi Sulawesi Selatan yang memang dari dulu terkenal masyarakatnya sebagai pelaut ulung.

Di antara daerah di Provinsi Sulawesi Selatan yang memiliki potensi laut adalah Kabupaten Takalar yang terletak di arah selatan ibukota propinsi Sulawesi Selatan yaitu Kota Makassar, tepatnya berada sekitar 45 km dari kota Makassar.Selain itu Kabupaten Takalar juga merupakan salah satu kabupaten yang secara geografis dikenal sebagai daerah kawasan pantai. Hal itutercermin di dalamnya terdapat sejumlah penduduk berprofesi sebagai nelayan dan bermatapencaharian utama sebagai penangkap ikan dan biota laut yaitu tepatnya di wilayah pesisir Galesong,

Mayoritas penduduk yang bermukim di wilayah pesisir Galesong bermata pencaharian nelayan.Pada umumnya jenis-jenis usaha tersebut dilakukan secara tradisional menurut sitem pengetahuan dan peralatan yang cukup sederhana. Pengetahuan dan teknologi tersebut diwarisi dari generasi terdahulu, yang kemudian ditransformasikan kepada generasi yang lebih muda melalaui proses sosisalisasi. Sistem pengetahuan dan teknologi tradisional dalam bidang penangkapan itu masih banyak sampai sekarang.

Salah satu kegiatan masyarakat nelayan dalam melakukan aktivitasnya dalam mencari hasil kekayaan laut adalah sebagai "Patorani" asal kata dari "torani", yaitu kegiatan nelayan untuk mencari telur ikan terbang. Nelayan Dalam proses pencarian hasil laut tersebut diperlukan waktu yang hingga berbulan sampai tiga bulanan dan dilakukan dan melibatkan banyak orang.

Nelayan patorani menempati dua wilayah Galesong yaitu Galesong Selatan dan Galesong Utara.Jumlah desa di dua kecamatan tersebut sebanyak 12 buah desa.Namun diantara desa-desa tersebut, terdapat lokasi yang dijadikan sebagai basis terbanyak ditempati oleh nelayan patorani yakni desa Galesong baru, Paklaklakkang dan Bontosunggu.Tempat ini, sejak dari dulu hingga sekarang menjadi tempat menyimpan (parkir) perahu komunitas nelayan patorani ketika kembali melakukan penangkapan.

Dalam kegiatan nelayan patorani melibatkan banyak banyak orang yang dikelompokkan dalam tiga bagian yaitu, papalele, pinggawa, dan sawi.Papalele adalah pemilik perahu dan sekaligus pemilik modal, pinggawa adalah pemimpin awak perahu, sementara sawi adalah buruh.Tiga kategori nelayan ini memainkan peran utama dalam terlaksananya kegiatan patorani.Papalele tidak pernah melaut dan ikut melakukan penangkapan, sedangkan pinggawa dan sawi adalah kelompok yang melakukan penangkapan.

Ketiga unsur nelayan tersebut antara papalele, punggawa dan sawi terjalin ikatan kontrak kerjasama, baik sebelum pemberangkatan, sedang dan setelah pulang dari pengkapan. Terjadinya jalinan ikatan pada papalele, pinggawa dan sawi sangat terkait dengan pembagian hasil tangkapan. Pembagian hasil tersebutantara papalele 
pinggawa dan sawi dilakukan setelah mengelurkan seluruh biaya operasional yang telah dikeluarkan selama kegiatan torani.

Adapun sistem bagi hasil yang diterapkan nelayan patorani adalah sistem bagi hasil tiga bagian setelah dipotong biaya operasinal oleh pemilik modal. Ketentuan bagi hasil atau pendapatan ini merupakan kesepakatan secara tidak tertulis yang secara umum telah menjadi tradisi turun-temurun dari nenek moyang hingga sekarang. Walaupun tidak tertutup kemungkinan adanya kesepakatan lain yang dilakukan secara ke dalam yang sifatnya personal oleh masing-masing pihak.

Pembagian hasil tangkapan patorani, apabila hasil yang diperoleh nelayan banyak, maka tentu tidak akan menjadi masalah karena mudah dalam membagi hasil usaha artinya ada barang atau hasil usaha yang akan dibagi kepada pemilik modal (papalele) pemimpin perahu (pinggawa) serta buruh perahu. Akan tetapi dalam usaha sebagai nelayan hasilnya tidak tentu dan apabila tidak mendapatkan hasil tangkapan sama sekali, maka bagaimana cara pembagian hasilnya? Ini merupakan suatu permasalahan yang harus dipecahkan.

Islam mengajarkan kepada pemeluknya untuk bekerja dan berusaha untuk mencari rezki yang telah disediakan oleh Allah di muka bumi untuk keberlangsungan kehidupannya baik secara perorangan maupun bekerjasama dengan orang lain. Dalam bentuk kerjasama dalam melakukan perbuatan dalam hubungannya dengan orang lain dalam Islam disebut Muamalah. Syari'at Islam telah memberikan aturan-aturan di dalam diri kita untuk melaksanakan hubungan kerja yang baik, saling tolong menolong, saling menguntungkan dan tanpa merugikan antara satu sama lain. Dengan demikian maka cara pembagian yang menjadi konsekkuensinya pun harus demikian adanya artinya bagian yang diterima oleh masing-masing pihak harus sesuai dengan pengorbanannya dan sesuai dengan pekerjaannya.

Berdasarkan uraian diatas, maka masalah utama dalam penelitian ini adalah: "Bagaimana pelaksanaan bagi hasil penangkapan telur ikan antara pemilik modal $\backslash$ (papalele), kepala perahu (pinggawa) serta buruh (sawi), apakah sesuai dengan system syari'at Islam?

\section{B. METODE PENELITIAN}

Jenis penelitian ini merupakan field research (penelitian lapangan) merupakan Pengumpulan data dan informasi yang diperoleh langsung oleh responden dan mengamati secara langsung proses pelaksanaan bagi hasil penangkapan telur ikan antara pemilik modal (palele), kepala perahu (pinggawa) serta buru (sawi).

Metode pengumpulan bersumber dari : 1. Data Primer, yaitu observasi dan wawancara 2. Data Sekunder, yaitu data yang diperoleh dari berbagai literatur, peraturan perundang-undangan, pendapat para ahli hukum, dokumen serta tulisan lain yang terkait materi yang dibahas sebagai penunjang.

Data yang diperoleh selama proses penelitian baik itu data primer dan sekunder dianalisis secara kualitatif kemudian disajikan secara deskriptif yaitu menguraikan, menggambarkan, dan menjelaskan sesuai dengan permasalahan yang erat kaitannya dengan penelitian ini. 
Muhammad Irfan

\section{PEMBAHASAN \\ Defensi Operasional}

Penelitian ini berfokus pada kajian konsep mudhorabah dalam system bagi hasil nelayan Patorani di Galesong Utara dan bagaimana tinjauan hukum Islam terhadap masalah tersebut.Berdasarkan pada fokus penelitian dari judul tersebut, maka dapat di deskripsikan substansi permasalahan pada fokus penelitian. Oleh karena itu, penulis memberikan defenisi operasional variabel sebagai berikut:

\section{Mudhorabah}

Secara bahasa Mudharabah adalah berasal dari kata adh dharb yangmemiliki relevansi antara keduanya, yaitu: Pertama karena yang melakukanusaha Yadhrib Fil Ardhi ( berjalan dimuka bumi) dengan berpergian untukberdagang, maka ia berhak mendapat keuntungan karena usaha dan kerjanya.Kedua karena masing-masing orang yang berserikat Yadhribu Bisahmin(mengambil bagian dalam keuntungan). ${ }^{1}$

Sedangkan The New Encyclopedia of Islam Memberikan pengertian:Mudharabah is a business partnership where one partner puts up the capitaland the other the labor: a sleeping partnership. ${ }^{2}$ Dari pengertian tersebut dapat diketahui bahwa Mudharabah adalahpemilik modal menyerahkan modalnya kepada Mudharib (pekerja) untukdimanfaatkan untuk tujuan usaha yang produktif dan halal.Sedangkan hasilkeuntungan dibagi menurut kesepakatan bersama.Apabila terjadi kerugiandalam perdagangan tersebut ditanggung sepenuhnya oleh shahibul maal (pemilik modal) sesuai proporsi modal yang di mudharabahkan. ${ }^{3}$

\section{Patorani.}

Secara etimologis, istilah "patorani" berasal dari bahasa Makassar, terdiri atas suku kata padan torani.Kata $p a$ dapat diartikan sebagai suatu sistem mata pencaharian yaitu nelayan,sedangkan kata torani adalah nama jenis ikan yang bisa terbang. Maka kata patoranimenunjukkan sekelompok orang dengan pekerjaan khusus pencari ikan terbang.

Dalam kegiatan nelayan patorani melibatkan banyak banyak orang yang dikelompokkan dalam tiga bagian yaitu, papalele(pemilik modal), pinggawa(Juragan), dan sawiburuh perahu.Ketiga unsur tersebut antara papalele, punggawa dan sawi terjalin kerjasama terkait dengan pembagian hasil tangkapan.Pembagian hasil tersebut antara papalele pinggawa dan sawi dilakukan setelah mengelurkan seluruh biaya operasional yang telah dikeluarkan selama kegiatan torani.

\section{Lokasi Penelitian}

Penelitian ini akan difokuskan di wilayah Galesong, daerah ini secara geografis terletak dipesisir selatan Kabupaten Takalar yang merupakan wilayah Provinsi Sulawesi Selatan. Daerah ini sangat mudah dijangkau dengan jarak $40 \mathrm{~km}$ dari Kota Metropolitan Makassar dan terletak antara $5^{\circ} 31$ sampai $5^{\circ} 381$ Lintang Selatan dan antara $199^{\circ} 221$ sampai $199^{\circ} 391$ Bujurlimur dengan luas wilayah 566,51 Km2.

\footnotetext{
${ }^{1}$ Muhammad, Teknik Perhitungan Bagi Hasil Dan Profit Margin Pada Bank Syari'ah (Cet. II; Yogyakarta: UII Press, 2004), h. 36.

${ }^{2}$ Huston Smith, The New Encyclopedia of Islam (North America: Altamira Press, Resived Edition, 2001), h.319.

${ }^{3}$ Abdul Azis Dahlan, Ensiklopedi Hukum Islam, Jilid 4 (Cet. I; Jakarta: Ichtiar Baru van Hoeve, 1996), h. 1196.
} 
Secara administratif pemerintahan wilayah Kabupaten Takalar terdiri dari 7 (tujuh)Kecamatan dan 77 desa/kelurahan yang terdiri dari 57 desa serta 20 Kelurahan. Dari 7(tujuh) kecamatan tersebut 4 (empat) kecamatan merupakan wilayah pesisir yaituMangarabombang dengan luas $100,50 \mathrm{Km} 2$ terdiri dari 11 desa dan 1 (satu) kelurahan,Mappakasunggu dengan luas 74,63 Km2 terdiri dari 7 Desa 1 Kelurahan, Galesong Selatanluas 44,00 Km2 terdiri dari 17 Desa, Galesong Utara dengan luas 21,75 Km2 terdiri dari 9desa. Tiga Kecamatan lainnya adalah Polombangkeng Selatan dengan luas 88,07 Km2 terdiridari 4 desa dan 4 kelurahan, Polombangkeng Utara dengan luas 212, $25 \mathrm{Km} 2$ terdiri atas 9desa dan 6 kelurahan, dan kecamatan Pattallassang dengan luas 25,31 Km2 terdiri dari 8Kelurahan.

Wilayah Galesong memanjang dari ujung desa Bontomarannu di Selatan sampai Batu-batu diUtara perbatasan Barombong di Makassar. Secara administratif, Kabupaten Takalar memiliki batas-batas wilayah antara lain; (1) sebelah Utara berbatasan Kota Makassar dan kabupaten Gowa; (2) sebelah Timur berbatasan Kabupaten Jeneponto; (3) sebelah Selatan berbatasan dengan laut Flores; (4) sebelah Barat berbatasan denganselat Makassar dan luas wilayah berkisar $566,51 \mathrm{~km} 2$.

Adapun jumlah kecamatan terdiri atas; Kecamatan Mappakasunggu, Mangngara bombang, Polong Bangkeng Utara, Polong Bangkeng Selatan, Galesong Selatan dan Kecamatan Galesong Utara. Galesong adalah salah satuwilayah penyokong ekonomi kabupaten Takalar sejak dulu, posisinya yang strategis karena berdekatan dengan kota metropolitan Makassar adalah keuntungan tersendiri. Secara geografis dikenal sebagai daerah kawasan pantai. Hal itu tercermin didalamnya sejumlah penduduk berprofesi sebagai nelayan dan bermata pencaharian utama sebagai penangkap ikan dan biota laut.

Kabupaten Takalar adalah wilayah yang beriklim tropis, sehingga hanya mengenal dua musim dalam setahunnya, yaitu musim hujan dan musim kemarau. Kedua musim ini, menjadikan rata-rata temperature udaranya sepanjang tahun berkisar antara 25-30C. Tlitik terendah berada di daerah-daerah ketinggian100 meter di atas permukaan laut yang letaknya sebagian besar di wilayah gugusan pantai (pantai selatan dan pantai barat). Titik tertinggi berada di daerah-daerah yang terletak di bawah kaki gunung. KabupatenTakalar memiliki enam kecamatan potensi unggulan untuk dijadikan sebagai sumber penghidupan masyarakatnya. Pemetaan potensi tersebut secara potensial masyarakatnya tergantung pada kondisi alam yang dimiliki.

\section{A. Analisis Terhadap Akad Perjanjian Mudharabah Hasil Patorani Di Galseong Utara Kabupaten Takalar.}

Perjanjian adalah suatu perbuatan dalam mencapai kesepakatan antara seseorang atau beberapa orang dengan seseorang atau beberapa orang lainya untuk melakukan sesuatu perbuatan tertentu. ${ }^{4}$ Sedangkan syarat perjanjian kerjasama harus dibuat secara tertulis dan atas kesepakatan antara kedua belah pihak, tidak boleh hanya sekedar diucapkan, Untuk dapat mempunyai kekuatan hukum tetap. ${ }^{5}$

\footnotetext{
${ }^{4}$ Chairuman pasaribu dan Suhrawardi K, Lubis, Hukum Perjanjian dalam Islam (Cet. II; Jakarta: Sinar Grafika, 1996), h. 4.

${ }^{5}$ Afzalur Rahman, Doktrin Ekonomi Islam, Jilid 2 (Yogyakarta: PT. Dana Bhakti Wakaf, 1995), h. 344
} 
Akad adalah suatu perikatan antara ijab dan kabul dengan cara yang dibenarkan syara' yang menetapkan adanya akibat hukum pada objeknya. ${ }^{6}$ Akan tetapi yang terjadi, nelayan patorani di Galesong Utara dalam bekerjasama bagi hasil penangkapan ikan akad perjanjian kerja baik dilakukan dalam bentuk lesan dan tidak ada bagi hasil yang jelas secara tertulis. Sedangkan dalam pelaksanaan bagi hasil di Galesong Utara dilakukan dengan mengikuti peraturan atau cara-cara yang telah berlaku sejak dulu dan turun-menurun kepada masyarakat setempat.

Ahmad Azhar Basyir, dalam bukunya Asas-Asas Hukum Mu'amalat (Hukum Perdata Islam) menjelaskan tentang pembentukan akad adalah: suatu hal yang harus diperhatikan rukun dan syaratnya. Rukun akad adalah ijab dan qabul sebab akad adalah suatu perikatan antara ijab dan qabul yang harus ada dalam suatu hal, peristiwa atau tindakan. Agar ijab dan qabul benar-benar mempunyai akibat hukum, diperlukan adanya tiga syarat sebagai berikut:

1. Ijab dan qabul harus dinyatakan oleh orang yang telah mencapai umur atau tamyiz (harus dinyatakan oleh orang yang cakap dalam melakukan tindakan hukum) untuk dapat mengetahui isi perkataan yang diucapkan sehingga ucapanya tersebut benar-benar menyatakan keinginan hatinya.

2. Ijab dan qabul harus tertuju pada suatu objek, yang merupakan objek akad.

3. Ijab dan qabul harus berhubungan langsung dalam satu majelis dan kedua belah pihak sama-sama hadir. ${ }^{7}$

Adapun syarat yang menyangkut subyek akad (papalele, punggawa dan sawi) dan obyek akad (kerja nelayan dan hasil yang akan diperoleh) adalah:

1. Telah ada pada waktu akad diadakan

2. Dapat menerima hukum akad

3. Dapat ditentukan dan dapat diketahui

4. Dapat diserahkan pada waktu akad terjadi.

Sedangkan menurut Chairuman pasaribu dan Suharwadi Lubis dalam bukunya Hukum Perjanjian Dalam Islam menjelaskan bahwa secara umum yang menjadi syarat syahnya suatu perjanjian adalah:

1. Perjanjian yang dibuat oleh para pihak tidak menyalahi hukum Syari'ah yang disepakati.

2. Perjanjian yang diadakan oleh para pihak haruslah di dasarkan pada kesepakatan dan atas kehendak masing-masing pihak

3. Perjanjian yang dibuat oleh para pihak harus jelas tentang apa yang menjadi isi perjanjian. Sehingga tidak mengaki batkan terjadinya kesalah pahaman diantara para pihak tentang apa yang telah mereka perjanjikan di kemudian hari. ${ }^{8}$

Jika dilihat dari teori yang dikembangkan oleh Ahmad Azhar Basyir, Chairuman pasaribu dan Suharwadi Lubis,terkait dengan syarat syahnya suatu perjanjian serta pembentukan akad adalah bahwa dalam suatu perjanjian yang dibuat antara kedua belah pihak harus sesuai dengan kesepakatan terhadap isi perjanjian. Dan perjanjianyang diadakan antara kedua belah pihak bukanlah perbuatan yang bertentangan dengan

\footnotetext{
${ }^{6}$ Ahmad Azhar Basyir, Asas-Asas Hukum Mu'amalat (Hukum Perdata Islam), Edisi Revisi, Yogyakarta: UII Press, 2000, hlm.65. 51

${ }^{7}$ Ahmad Azhar Basyir, Asas-Asas Hukum Mu'amalat (Hukum Perdata Islam), h. 66.

${ }^{8}$ Chairuman pasaribu dan Suhrawardi K, Lubis, Hukum Perjanjian dalam Islam, h. 2-3.
} 
hukum atau perbuatan yang melawan hukum Syari'ah. Demikian juga ijab dan qabul merupakan penetapan atas keridhaan kedua pihak, atau dapat dikatakan bahwa akad adalah suatu perbuatan yang sengaja dibuat oleh dua orang dan berdasarkan keridhaan masing-masing pihak.

Adapun yang terjadi di lapangan, perjanjian yang dilakukan antara Papalele, punggawa dan sawi di Galesong Utara secara hukum sudah sesuai dalam hukum Islam. Karena telah memenuhi rukun dan syarat akad.

Dari segi rukun akad adanya ijab dan qabulantara kedua pihak dilakukan secara lesan, dengan mengikuti peraturan-peraturan dan cara-cara yang telah berlaku dalam masyarakat, yang mana peraturan tersebut ditentukan oleh para pihak yang tergabung dalam kerjasama bagi hasil. Dan orang yang menjalankan akad adalah orang yang telah tamyiz, ijab dan qabul dilakukan dalam satu majlis dan dihadiri oleh masing-masing pihak), ijab dan qabul tertuju pada obyek akad (kerja nelayan dan hasil yang diperoleh) dan subyek akad (papalele, punggawa dan sawi).Hal ini sesuai dengan keadaan di lapangan yang dilakukan antara papalele, punggawa dan sawi dalam akad perjanjian kerja bagi hasil attorani.

Akan tetapi dalam pembagian hasil antara papalele, punggawa dan sawi tidak sesuai karena terdapat ketidakadilan yaitu adanya biaya perbekalan hutang, dan itu menjadi tanggungan papalele. Sedangkan kerjasama antara papalele, punggawa dan sawi hanya sebatas pemilik modal dan seseorang yang menjalakan suatu usaha dengan cara bagi hasil. Sebab ada orang yang mempunyai modal, tetapi orang tersebut tidak mempunyai keahlian dalam menjalankan usaha. Ada juga orang yang tidak mempunyai modal tetapi orang tersebut mempunyai keahlian.

Dengan demikian dibutuhkan adanya kerjasama antara kedua belah pihak dalam mendapatkan keuntungan (modal) dan skill (keterampilan). Sebagaimana Firman Allah dalam QS. Al-Baqarah:198

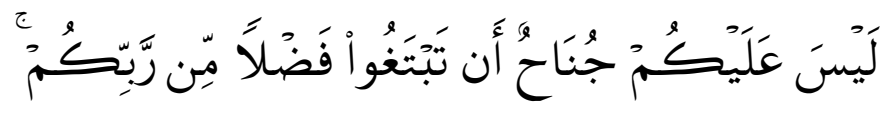

Artinya:

Tidak ada dosa bagimu untuk mencari karunia (rezeki hasil perniagaan) dari Tuhanmu. (Al-Baqarah: 198). ${ }^{9}$

Ayat di atas menunjukkan pengakuan Allah Swt akan adanya perserikatan atau kerjasama dengan mencari rizki hasil perniagaan dijalan Allah. Secara umum membolehkan manusia untuk bekerja, dengan tujuan untuk saling membantu antara pemilik modal dan pekerja untuk memutarkan uang atau menjalankan usahanya. Dalam akad kerjasama bagi hasil modal tergolong dalam bentuk akad mudharabah. Akad mudharabah adalah pemilik modal menyerahkan modalnya kepada pekerja untuk di jalankan, dengan membagi keuntungan menurut kesepakatan bersama.

Adapun modal dalam kerjasama bagi hasil penangkapan ikan, baik dalam bentuk akad Mudharabah mulai dari alat transportasi (kapal) dan semua peralatan nelayan serta biaya perbekalan semua dari juragan. Nelayan tidak mengeluarkan modal sama sekali,

${ }^{9}$ Departemen Agama RI, Al-Qur'an dan Terjemahannya (Solo: Pustaka Mantiq, 19970), h.48. 
nelayan hanya sebagai pekerja dan orang yang menjalankan usaha untuk mencari dan penangkap ikan di laut.

Adapun tentang perjanjian hutang perbekalan antara papalele, punggawa dan sawi, juga tidak ada ketentuan yang mengatur dengan jelas dan tegas tentang penyelesaian hutang perbekalan.Yang ada dalam penyelesaian hutang perbekalan tersebut tetap di bebankan kepada juragan kapal untuk membayar hutang perbekalan selama melaut. Hal ini terdapat ketidakadilan dalam bekerjasama bagi hasil antara papalele, punggawa dan sawi, kalaupun ada tanggungan hutang harus diselesaikan antara kedua belah pihak, bukan hanya salah satu pihak yang menanggung hutang dan hanya dibebankan kepada juragan saja.

Dalam hidup bermasyarakat manusia selalu berhubungan satu sama lain, untuk mencukupi kebutuhan hidupnya, pergaulan sebagai tempat setiap orang melakukan perbuatan dalam hubungannya dengan orang lain disebut Muamalah. Sebagai makluk sosial kebutuhan akan kerjasama antara satu pihak dengan pihak lain guna meningkatkan taraf perekonomian dan kebutuhan hidup tidak bias diabaikan. ${ }^{10}$ Sebagaimana Firman Allah dalam QS. An-nisaa: 29

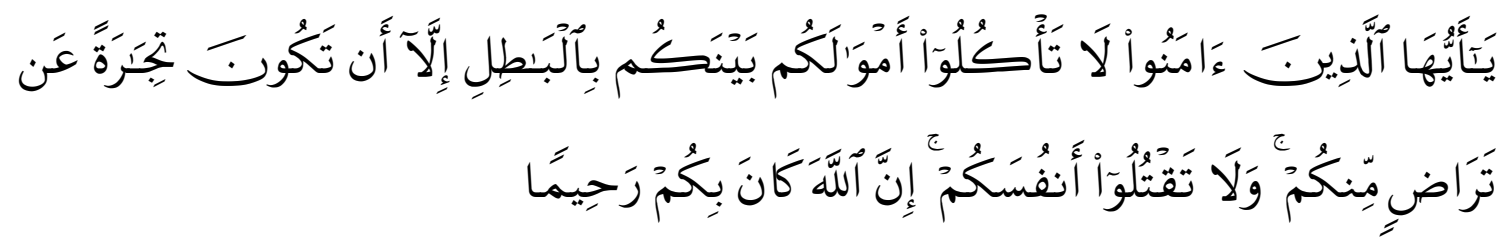

Terjemahan:

Hai orang-orang yang beriman, janganlah kamu saling memakai harta sesuatu dengan jalan yang bathil, kecuali dengan jalan perniagaan yang berlaku dengan jalan sukasama suka diantara kamu.Dan janganlah kamu membunuh dirimu. Sesungguhnya allah adalah maha penyayang kepadamu.(An-Nisaa: 29). ${ }^{11}$

Ayat di atas menerangkan tentang ketentuan bahwa dalam perdangangan atau kerjasama atas dasar sukarela merupakan salah satu bentuk mu'amalah yang halal. Setiap pelaku ekonomi harus berpedoman pada asas dan peraturan menurut Al Qur'an dan Hadis selain itu juga harus memperhatikan nilai-nilai Islam, apabila ingin mencapai keuntungan dunia akhirat, yakni keuntungan yang ingin ditimbang tidak hanya didunia saja tetapi harus diperhitungkan keabsahanya sampai akhirat. ${ }^{12}$ Dalam kerjasama bagi hasil antara papalele, punggawa dan sawidi Galesong Utara cenderung punggawa lebih dirugikan. Tapi dalam kenyataannya juragan harus bisa menerima dan tidak bisa berbuat banyak dengan alasan untuk tolong menolong dan saling bekerjasama agar tetap beroperasi dan mendapat hasil serta agar tetap bisa bekerja, walaupun dalam hal ini punggawa harus dirugikan dan terus menerus menanggung kerugian.

Menurut pengamatan penulis dari hasil penelitian di lapangan, tentang akad perjanjian yang dilakukan antara papalele, punggawa dan sawi tidak ada bentuk akad

\footnotetext{
${ }^{10}$ Ibrahim Lubis, Ekonomi Islam Suatu Pengantar (Cet. I; Jakarta: Radar Jaya Offset, 1995), h.423-424.

${ }^{11}$ Departemen Agama RI, Al-Qur'an dan Terjemahannya, h.122.

${ }^{12}$ Ahmad M. Saefuddin, Ekonomi Masyarakat Dalam Perspektif Hukum Islam (Cet. I; Jakarta: Rajawali, 1987), h. 125.
} 
yang mengatur tentang perjanjian kerjasama, baik akad perjanjian kerja, modal, bagi hasil maupun adanya hutang piutang. Yang ada dalam pelaksanaan bagi hasil torani tersebut adalah para pihak hanya melaksanakan ketentuan dari dulu secara turun menurun tentang apa yang mereka ketahui, tanpa dilandasi oleh adanya akad perjanjian yang jelas sesuai dengan hukum Islam maupun hukum positif.

\section{PENUTUP}

\section{Kesimpulan}

Berdasarkan penelitian di atas, maka dapat disimpulkan sebagai berikut:

1. Kerjasama bagi hasil penangkapan ikan akad perjanjian antara nelayan dan juragan adalah dilakukan secara lisan, dengan mengikuti adat kebiasaan yang berlaku secara turun temurun. Dan dalam pelaksanaan kerjasama bagi hasil tersebut adalah hanya sebatas kerja dan mendapatkan hasil.

2. Adapaun akad perjanjian bagi hasil nelayan patorani sudah memenuhi rukun dan syarat. Rukun akad yaitu adanya ijab dan qabul, adanya subyek akad (nelayan dan juragan) dan obyek akad (kerja nelayan dan hasil yang akan diperoleh). Mengenai syarat-syaratnya juga telah terpenuhi baik yang berhubungan dengan ijab dan qabul, dan yang berhubungan dengan subyek akad maupun yang berhubungan dengan obyek akad. Nelayan dan juragan sebagai subyek akad dan obyek akad sudah memenuhi syarat yaitu telahadap ada waktu akad diadakan, dapat menerima hukum akad dan dapat diserahkan pada waktu akad terjadi.

3. akad perjanjian bagi hasil penangkapan ikan yang dilakukan oleh nelayan patorani adalah sah menurut hukum Islam karena telah memenuhi syarat-syarat dan rukun. Dilihat dari system bagi hasil maka dapat dikatakan bahwa pembagian tersebut sudah cukup adil meskipun terdapat ketidakadilan tentang kerugian dalam kerjasama bagi hasil, dalam hal ini adanya hutang yang dibebankan kepada juragan.

4. Bagi hasil antara nelayan patorani menggunakan sistem mudharabah Muthlaqah yaitu mengikuti adat kebiasaan yang berlaku di daerah setempat dengan menggunakan cara tata cara pembagian yang disepakati bersama.

\section{DAFTAR PUSTAKA}

AzharBasyir, Ahmad, Asas-AsasHukum Muamalah. Yogyakarta: UII Press, 2000 Adi, Rianto, Metodologi Penelitian Sosial Dan Hukum. Jakarta: Granit, 2004

Arikunto, Suharsimi, Prosedur Penelitian Suatu Pendekatan Praktek. Jakarta: Rineka Cipta, 2002

Antonio, Syafi'I, Muhammad. Bank Syari'ah: Dari Teori dan Praktek, Jakarta: Gema Insani Press, 2001

Abdullah Saeed, Bank Islam Dan Bunga: Studi Kritis Interprestasi Kontemporer Tentang Riba dan Bunga. Yogyakarta: Pustaka Pelajar, 2008

Chairuman pasaribu dan Suhrawardi K, Lubis, SH, HukumPerjanjian Dalam Islam, Jakarta: Sinar Grafika, 1996

Dahlan, Abdul Aziz, EnsiklopediHukum Islam, Jakarta: IchtiarBaru Van Hoeve, 1996

Dewi, Gemala et al, HukumPerikatan Islam di Indonesia, Jakarta: Kencana Prenada Media Group, 2006

Departemen Agama RI. Al-Qur'an dan Terjemahannya. Solo: PustakaMantiq, 1997 
Muhammad Irfan

Hassan Shadily, Ensiklopedi Indonesia, Ichtiar Baru-Van Hoeve, 1983

Helmi Karim, FiqhMu'amalah. Jakarta: Raja Grafindo Persada, 1993

Hasan, M. Ali, Berbagai MacamTransaksi dalam Islam, Jakarta: Raja GrafindoPersada, 2003 Kusnadi, Konflik Sosial Nelayan, Yogyakarta: LKIS, 2002

----------, Nelayan: Strategi Adaptasi dan Jaringan Sosial, Bandung: Humaniora Utama Press, 2000

Lubis, Ibrahim, Ekonomi Islam Suatu Pengantar. Jakarta: Radar Jaya Qffset, 1995.

Masri Singarimbun dan Sofian Effendi, MetodePenelitian Survey, Jakarta: LP3ES, 1989

M. Rifa'ii, Terjemah Khulashah: Kifayatul Akhyar, Semarang: PT KaryaToha Putra

, Terjemah Bulughul Maram, Semarang: Wicaksana, 1994

Muhammad, Sistem dan Prosedur Operasional Bank Syari'ah,Yogyakarta: UII Press, 2000

--, Teknik Perhitungan Bagi Hasil dan Profit Margin Pada Bank Syari'ah, Yogyakarta: UII Press, 2004

Mas'adi, Ghufron A, Fiqh Muamalah Kontekstual. Jakarta: Raja Gafindo Persada, 2002

M. Saefuddin, Ahmad, Ekonomi Masyarakat dalam Perspektif Hukum Islam. Jakarta: Rajawali, 1987

Mervvyn K. Lewis dan LatifaAlgaoud, Perbankan Syari'ah. Jakarta: Serambi Ilmu Semesta, 2004

Mulyadi, Ekonomi Kelautan. Jakarta: Raja GrafindoPersada, 2005

U. Maman, et, al. Metodologi Penelitian Agama: Teori Dan Praktek. Jakarta: Raja GrafindoPersada, 2006

Prof. R. Subekti, SH. dan R. Tjitrosudibio, Kitab Undang-undang Hukum Perdata. Jakarta: Pradnya Paramita, 1999.

Rahman, Afzalur, Doktrin Ekonomi Islam. Yogyakarta: PT. Dana Bhakti Wakaf, 1995 